\title{
Analysis of genetic diversity of bacteria Xanthomonas oryzae pv. oryzae causes leaf blight in North Sumatra
}

\author{
Zulheri Noer ${ }^{1 *}$, Maimunah ${ }^{1}$, Erwin Pane ${ }^{1}$, Eko Prasetya ${ }^{2}$ \\ ${ }^{1}$ Departement of Agrotechnology, Faculty of Agriculture, Universitas Medan Area \\ Jl. Kolam No. 1 Medan Estate/Jl. Gedung PBSI, Medan, North Sumatra, Indonesia. 20223 \\ *Email: z_noer@yahoo.co.id \\ ${ }^{2}$ Department of Biology, Faculty of Mathematics and Natural Sciences, Universitas Negeri Medan \\ Jl. Willem Iskandar, Pasar V, Medan, North Sumatra, Indonesia. 20221
}

\begin{abstract}
Xanthomonas oryzae pv. oryzae (Xoo) causes bacterial leaf blight on rice plants, which is responsible for crop failure, resulting in economic losses. Control of Xoo bacteria can be accomplished through the use of Xoo-resistant rice varieties. Due to the shifting genetic structure and environmental conditions of Xoo bacteria, it is difficult to identify them according to their pathotype. This study aims to determine the genetic diversity of Xoo bacteria using the polymerase chain reaction (PCR) method and the IS1112-based RAPD marker, which is known to contain repetitive sequences. DNA was isolated from 52 isolates collected from 15 districts and cities in North Sumatra province and then used to amplify the IS1112 sequence. Dendrogram analysis revealed that cluster analysis of PCR findings classified isolates into 15 groups with a $90 \%$ similarity value. Genetic variation among Xoo isolates from North Sumatra ranged between $51 \%$ and $100 \%$. North Sumatra Xoo isolates exhibited a high degree of genetic diversity. This findings can be used as a resource for future management of the Xoo bacteria by expediting disease-resistant rice breeding projects in various rice producing countries.
\end{abstract}

Keywords: bacterial leaf blight (BLB); IS1112 sequence; PCR-RAPD; principal component analysis; similarity index

Article History: Received 10 September 2021; Received in revised form 30 October 2021; Accepted 14 November 2021; Available online 30 December 2021

How to Cite This Article: Noer Z, Maimunah M, Pane E, Prasetya E. 2021. Analysis of genetic diversity of bacteria Xanthomonas oryzae pv. oryzae causes leaf blight in North Sumatra. Biogenesis: Jurnal Ilmiah Biologi. vol 9(2): 198-205. doi: https://doi.org/10.24252/bio.v9i2.24092.

\section{INTRODUCTION}

Bacterial leaf blight is caused by Xanthomonas oryzae pv. oryzae (Xoo), a rice plant pathogen that has been widely reported to have spread throughout south-east Asia, including Indonesia (Suryadi et al., 2016; Patil et al., 2017; Joshi et al., 2020), Northern Australia (Islam et al., 2016), Africa (Joshi et al., 2020), America, the Caribbean islands, and various other regions throughout the world (Khan et al., 2014; Islam et al., 2016). In Indonesia, this disease has spread to 28743 ha of rice fields, whereas bacterial leaf blight has infected 1918 ha of rice fields in North Sumatra (Kementerian Pertanian, 2021). Crop failure rates due to bacterial leaf blight exceed $50 \%$, resulting in enormous economic losses (Gautam et al., 2015; Kementerian Pertanian, 2015). Rice plants are infected by Xoo bacteria via seeds, damaged tissues, hydathodes, stomata or wound (Wahyudi et al., 2011; Zhao et al., 2012). Infected rice plants exhibit yellow leaves that wither over time during the seedling stage. Additionally, when a malignant Xoo strain is present, the lesions grow rotten and the leaves develop yellow to white water-soaked stripes and dark patches (Khan et al., 2014; Verma et al., 2019).

Numerous research and approaches to disease control have been conducted, but none have been demonstrated to be effective in containing Xoo bacteria outbreaks (Gautam et al., 2015). Currently, the most effective approach of reducing bacterial leaf blight is through the introduction of resistant rice cultivars (Tasliah, 2012; Khan et al., 2014; Chukwu et al., 2019). However, caution should be exercised when using resistant cultivars, as they can still be attacked by Xoo strain to produce effectors with variation, carrying more virulent strains (Sudir \& Yuliani, 2016; Xu et al., 2019; Pradhan et al., 2020). Furthermore, the bulk of resistance genes revealed in rice plants confer resistance on Xoo strain, allowing the Xoo pathotype structure to evolve resistance 
in response to genetic alterations and geographic isolation.

The high genetic diversity of Xoo bacteria comes from a large rice-producing country in Asia such as Indonesia (Djatmiko et al., 2011; Sudir \& Yuliani, 2016). Additionally, more than 33 strains of Xoo have been found from a variety of rice-producing countries worldwide (Oliva et al., 2019; Luo et al., 2021). The genetic diversity of the Xoo strain can be identified from its transposons, virulence genes and insertion sequences (IS), one of them using DNA analysis with IS1112 sequence (Mishra et al., 2013; Yang et al., 2013; Deng et al., 2016).

IS1112 is a type of primer based on RAPD PCR (Shahrestani et al., 2012), which capable of identifying Xoo pathogen isolates and detecting genetic diversity within a population by analyzing specific DNA fragments (Yugander et al., 2017; Chen et al., 2019). JEL1 and JEL-2 are two IS1112 primers that are frequently used to analyze the variety of Xoo strain (Islam et al., 2016; Manigundan et al., 2017; Sandhu et al., 2018). JEL-1 and JEL-2 are multi-locus primers based on the IS1112 repeat found in the Xoo (Islam et al., 2016). Manigundan et al. (2017) analyzed the diversity of 23 Xoo bacteria isolates from India and the Gulf Islands using the IS1112 genome. Additionally, there is existing information about Xoo bacteria isolates from many countries, but knowledge regarding the Xoo diversity in Indonesia, particularly North Sumatra, is still limited. This study aims to determine the genetic diversity of Xoo isolates from North Sumatra, using the IS1112-based RAPD PCR approach. Additional isolates from all rice-growing regions must be studied to completely understand the population structure of $X$. oryzae pv. oryzae in North Sumatra, which will aid in the selection of resistance genes for breeding programs.

\section{MATERIALS AND METHODS}

Identification of Xanthomonas oryzae pv. oryzae leaf blight of rice. The study population of $X$. oryzae pv. oryzae were obtained from planting centers in North Sumatra about 132 samples. The isolates were then tested by growing on wakimoto agar (WA) medium
(Quibod et al., 2020). Bacterial colonies that showed yellow colour was followed by identification using Xoo-specific primers: Xoo2976F (5'-GCC-GTT-TTC-TTC-CTCAGC-3') and Xoo2976R (5'-AGG-AAAGGG-TTT-GTG-GAA-GC-3' ) (Lang et al., 2010; Tasliah et al., 2016). Approximately 52 Xoo samples were identified from 132 field samples collected in the districts of Asahan, Batubara, Binjai, Labuhan Batu Utara, Langkat, Mandailing Natal, Tapanuli Selatan, Tapanuli Tengah, Serdang Bedagai, Padang Lawas Utara, Simalungun, Tapanuli Utara, and Toba Samosir. The number of samples and the origin of the samples are presented in Table 1.

Table 1. Xanthomonas oryzae pv. oryzae isolated from 13 districts of the North Sumatra.

\begin{tabular}{lll}
\hline No & Origin of isolate (regency) & $\begin{array}{l}\text { Number of } \\
\text { samples }\end{array}$ \\
\hline 1 & Asahan & 12 \\
2 & Batubara & 2 \\
3 & Deli Serdang & 8 \\
4 & Labuhan Batu Utara & 1 \\
5 & Langkat \& Binjai & 10 \\
6 & Mandailing Natal & 3 \\
7 & Tapanuli Selatan & 1 \\
8 & Tapanuli Tengah & 1 \\
9 & Serdang Bedagai & 1 \\
10 & Padang Lawas Utara & 2 \\
11 & Simalungun & 6 \\
12 & Tapanuli Utara & 2 \\
13 & Toba Samosir & 3 \\
\multicolumn{7}{l}{ Total } & & 52 \\
\hline
\end{tabular}

DNA isolation. Isolates from each sample were cultured on WA in a test tube and incubated for 3 days. Then the Xoo culture was grown in a $250 \mathrm{ml}$ erlenmeyer containing $20 \mathrm{ml}$ of nutrient broth (NB) liquid medium and incubated overnight in a shaker at room temperature. A total of $1 \mathrm{ml}$ of Xoo culture was transferred into a $1.5 \mathrm{ml}$ tube, then centrifuged at $14000 \mathrm{rpm}$ with an IEC Micro-MB centrifuge for $1 \mathrm{~min}$. The supernatant was subsequently discarded. The exact process was repeated once. The resulting pellets then underwent DNA isolation process, carried out using the wizard genomic DNA purification system kit extraction (Promega, A1120). The quality of the isolated DNA was measured using the spectrophotometer at $260 \mathrm{~nm}$ and $280 \mathrm{~nm}$ (Pachchigar et al., 2016). 
DNA amplification. IS1112 PCR analysis was carried out with a PCR machine for DNA amplification, using a mixed solution containing $15 \mu \mathrm{l}$ Easy Do PCR pre Mix, $5 \mu \mathrm{l}$ working DNA with $20 \mathrm{ng} \mu \mathrm{l}-1$ and $5 \mu \mathrm{l}$ primer 10 pmol $\mu 1-1$. The primers used were JEL-1 and JEL-2. Furthermore, electrophoresis was carried out on $1.5 \%$ agarose gel with DNA marker. The electrophoresis was carried out for $90 \mathrm{~min}$ at $80 \mathrm{~V}$. The IS1112 PCR steps were carried out with cycles, and temperature settings were presented in Table 2. The PCR results were stained with loading dye and $1 \mathrm{~kb}$ DNA ladder, then separated on a long $2 \%$ agarose gel. The gel was stained with Ethidium bromide and visualized under UV light on a Chemidoc Bio-Rad ${ }^{\mathrm{TM}}$ device.

Table 2. PCR cycle and temperature regulation for IS1112 analysis (Islam et al., 2016).

\begin{tabular}{lccc}
\hline Fase & $\begin{array}{c}\text { Temperature } \\
\left({ }^{\circ} \mathrm{C}\right)\end{array}$ & $\begin{array}{c}\text { Duration } \\
(\text { Min })\end{array}$ & Cycles \\
\hline Pre- & 94 & 5 & 1 \\
denaturation & & & \\
Denaturation & 94 & 1 & 30 \\
Annealing & 62 & 1.5 & 30 \\
Extension & 65 & 1 & 30 \\
Post & 65 & 8 & 1 \\
extension & & & \\
\hline
\end{tabular}

Data analysis. The data collected in the form of DNA bands is converted to binary data by assigning a score (value), with 1 indicating the presence of a DNA band and 0 indicating the absence of a DNA band. This information is used to determine the similarity relationship of the Xoo isolates. Cluster analysis was based on the similarity coefficient with UPGMA using the numerical taxonomy and multivariate system (NTSys) ver 1.8. Principal component analysis (PCA) and heat map analysis were performed using the ClustVis ver 2.0 (https://biit.cs.ut.ee/clustvis) and $\mathrm{R}$ software (Metsalu \& Vilo, 2015).

\section{RESULTS AND DISCUSSION}

Xanthomonas oryzae pv. oryzae isolates were obtained from all rice cultivation centers in North Sumatra. Using WA's medium as a selection medium, 52 isolates produced yellow, small, and round colonies. Yellow-colored colonies on WA media are a morphological characteristic of Xoo bacteria (Djatmiko et al., 2011; Arshad et al., 2015). Bacterial colonies of the genus Xanthomonas grew yellow on WA media due to the presence of xanthomodin (He et al., 2020). The PCR result with Xoo2976 primer was declared as $X$. oryzae pv. oryzae if the DNA band was positioned at $337 \mathrm{bp}$. This result is also consistent with the findings of Tasliah et al. (2012), Saputra et al. (2020), and Fatimah et al. (2021). According to the PCR tests on 70 bacterial isolates, 52 were $X o$ o bacteria and 18 were not. A total of $52 \mathrm{Xoo}$ isolates was performed using a PCR marker based on IS1112 with specific primers JEL-1 and JEL-2. It successfully amplified two to seven DNA bands of Xoo isolates, with amplification products ranging from $0.3 \mathrm{~kb}$ to $12 \mathrm{~kb}$ (Fig. 1).

The Jaccards similarity coefficient calculates two-way data from the results of PCR analysis. The highest similarity was $83.3 \%$ which was found between Xo-240 with Xo-262, Xo-250 with Xo-256, Xo-053 with Xo-256, Xo-240 with Xo-256, Xo-219 with Xo-250, Xo-011 with Xo-012, and Xo-254 with $\mathrm{Xo}-104$, while the lowest similarity value is 0.50 witch was found between Xo-080, Xo100, Xo-089 and 49 other samples.

Fig. 2 illustrates the dendrogram generated using the UPGMA with specific IS1112 primers. All observed isolates had a similarity index more than $50 \%$. Isolates were classified into four groups based on their similarity index of $65 \%$. Grouping based on the amplification of specific IS1112 primers revealed that all isolates were classified into 15 clusters with a $90 \%$ similarity value. Cluster III has the most members (18 isolates), followed by cluster I (12 isolates), cluster VI (4 isolates), cluster VIII (4 isolates), cluster XI (3 isolates), cluster II, cluster V, cluster VII, cluster IX, cluster X, cluster XII, cluster XIII, cluster XIV, and cluster IV (1 isolate). Additionally, the UPGMA analysis demonstrates that the variants in Xoo are broadly distributed and do not cluster according to the sampling area. 

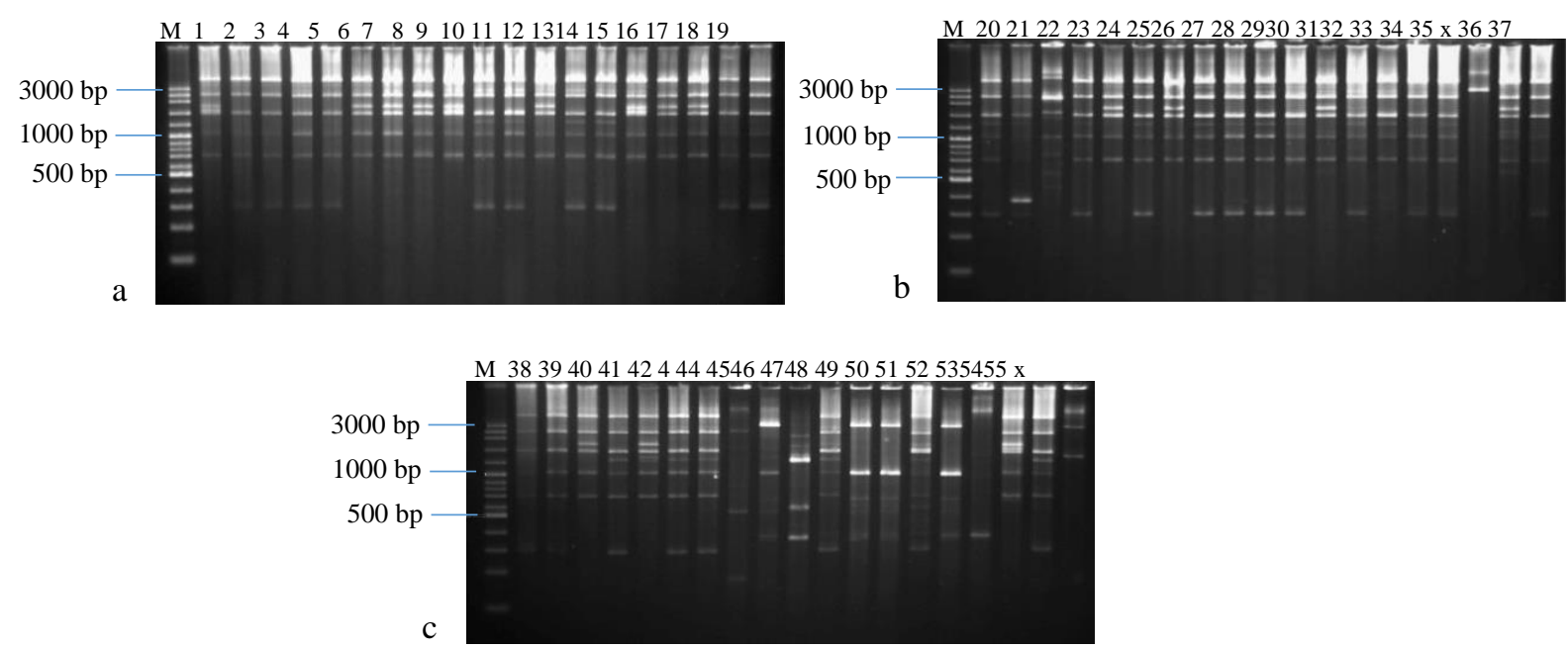

Fig. 1. PCR results used IS1112-based JEL-1 and JEL-2 primers of Xanthomonas oryzae pv. oryzae obtained from 13 districs in North Sumatra: a. Isolates 1-19; b. Isolates 20-37; c. Isolates 38-55 (M= marker 100 bp).

The Xoo pathogen race was identified based on its ability to induce compatible and incompatible reactions in a typical differential host cultivar. The diversity of hosts has no effect on the diversity of pathogens. However, the level of virulence of Xoo bacteria is increasing at the moment, owing to the diversity of rice cultivars planted, the varied growing and climatic circumstances in Indonesia (Djatmiko et al., 2011; Suryadi \& Kadir, 2017). The sampling location in this study is between 50 and 1200 masl, with average climatic of temperature $20-36^{\circ} \mathrm{C}$, humidity $60-95 \%$, wind speed $0.78-12 \mathrm{~m} / \mathrm{s}$, air pressure $970-1000 \mathrm{mb}$, rainfall of $2740-4380 \mathrm{~mm}$, rainy days $200-280$ days, and evaporation of 2.7-5.0 $\mathrm{mm} /$ day (Badan Pusat Statistik Provinsi Sumatera Utara, 2021). As a result, it may be concluded that the host rice from the Xoo isolate employed in this investigation grew under distinct conditions.

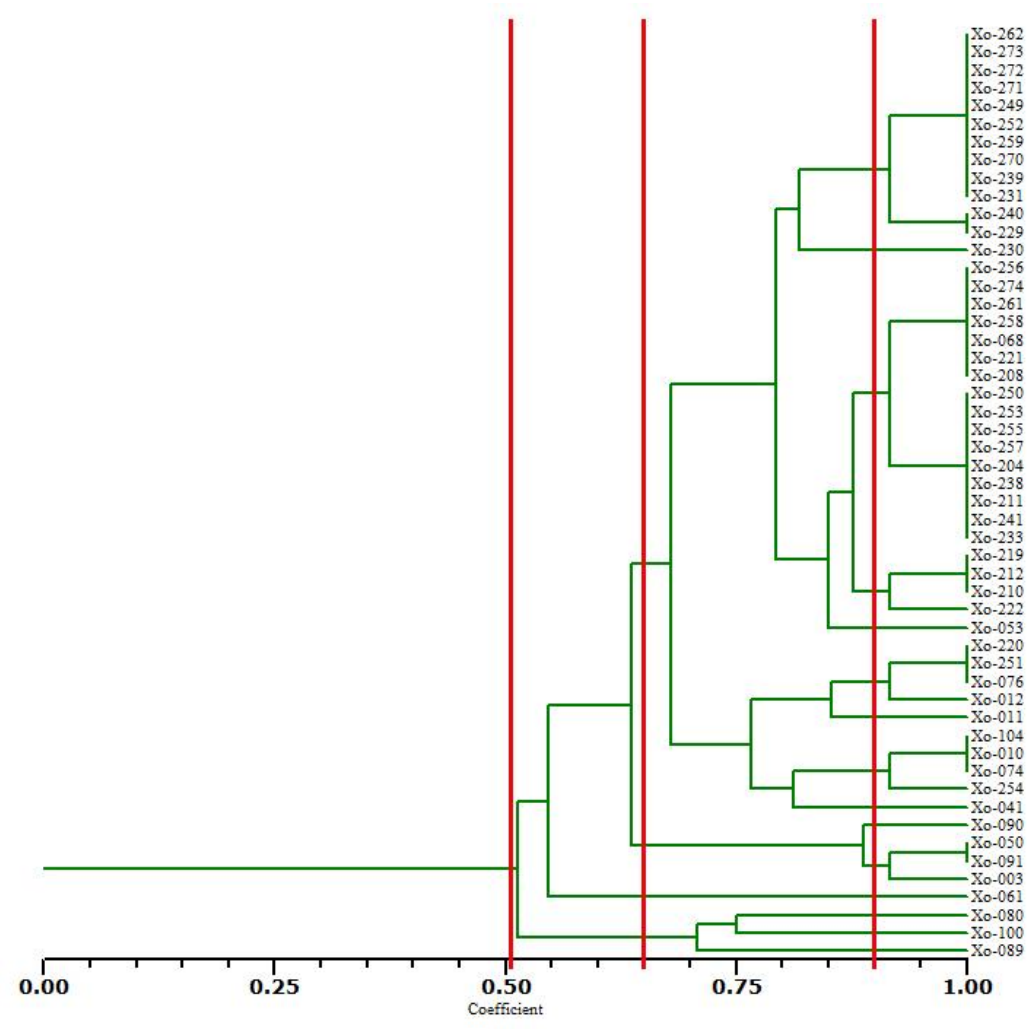

Fig. 2. The dendrogram using the UPGMA based on IS1112 sequence. 
The dendrogram is constructed using data from the Xoo DNA polymorphism. All strains acquired from diverse diseases, genetic profiles, and geographic locations exhibit intricate interactions. Another critical component is the interaction impact between the pathogen and its host, which results in changes to the pathogen's structure via a mutation process, resulting in a high level of DNA polymorphism. This results in changes in the pathogen population's structure due to mutation or recombination in order to adapt to new resistant host plants or climatic change (Islam et al., 2016).

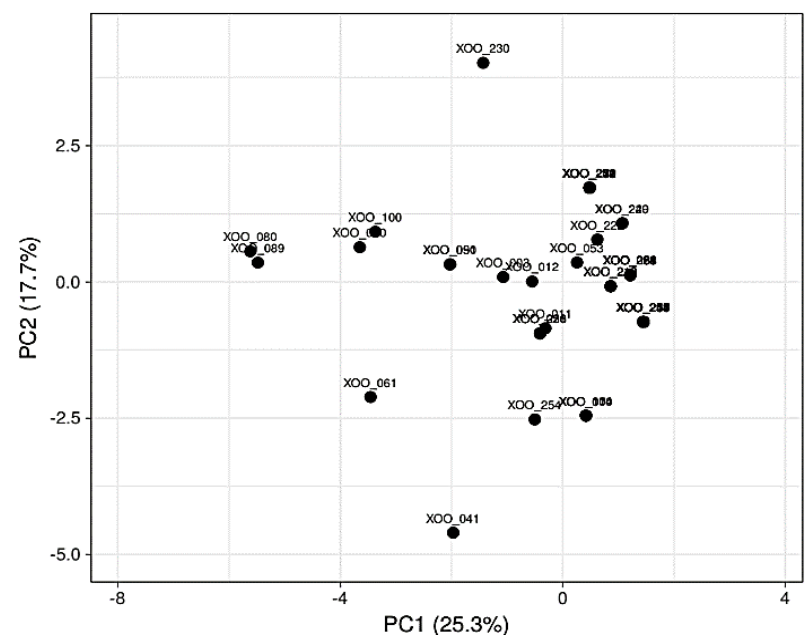

Fig. 3. Two-dimensional principal component analysis of 52 isolates of Xoo base of differences in RAPD fingerprint pattern IS1112-based using JEL-1 and JEL-2 primers.

The evolution of DNA amplification techniques has resulted in the development of a very sensitive approach. Amplification of RAPD fragments using random oligomeric primers has been widely utilized to discover genetic variation in eukaryotic and prokaryotic organisms. Recently, the PCR-RAPD technique has been shown to be effective at classifying a variety of microbial strains (UrreaValencia et al., 2021), including several Xanthomonas species (Shahrestani et al., 2012). JEL1 and JEL2 primers were used to amplify the IS1112 sequence since they have been found to be useful in categorizing pathotypes utilizing the PCR technique. Due to the high degree of heterogeneity and the absence of virulence grouping by region, it is impossible to classify virulence by region.
There is no grouping of samples by region using PCA (Fig. 3).

The first and second PCs are plotted in Fig. 4 using 259 printed polymorphic RAPD bands, which accounted for $25.3 \%$ and $17.7 \%$ of the overall variation, respectively. The twodimensional map demonstrates that the diversity in the 52 Xoo samples is relatively dispersed. pJEL101, a repetitive satellite region recovered from $\mathrm{Xoo}$, has been demonstrated to be a viable DNA marker. The Xoo population's diversity was determined using DNA markers and virulence pathotypes. In Japan, China, Philippines, Indonesia, and India, among other countries, bacterial strains were classified using a series of tests using resistant differential varieties and pathotypes (Mondal et al., 2014; Noer et al., 2018; Chen et al., 2020). The determination of virulence pathotypes reveals a high degree of pathogenicity diversity among bacterial strains (Sakthivel et al., 2017; Timilsina et al., 2020), posing a significant constraint on resistance breeding programs. To evaluate pathogen specialization under these settings, it is critical to conduct an extended pathogenicity survey using a large number of randomly generated isolates that appropriately reflect the pathogen population.

The genetic characterization of Xoo isolates enables further researchers to describe isolates belonging to the same group or race in order to examine the diversity of Xoo pathogens in a geographic area and develop more effective management strategies. By employing IS1112based randomized primers, unique molecular markers can be employed effectively for strain or isolate identification, as well as for measuring genetic variability and population structure in Xoo.

\section{CONCLUSION}

Using RAPD, Xanthomonas oryzae pv. oryzae isolates from the province of North Sumatra, Indonesia, were classified into 15 clusters with a similarity index of $90 \%$ based on their IS 1112 sequences. Cluster III had the most members (18 isolates), followed by cluster I (12 isolates), cluster IV (5 isolates), cluster VI (4 isolates), cluster VIII (4 isolates), cluster XI (3 isolates), cluster II, cluster V, cluster VII, 
cluster IX, cluster X, cluster XII, cluster XIII, cluster XIV, and cluster IV (1 isolate). Cluster analysis indicates that the variance of Xoo isolates based on molecular analysis ranges between $51 \%$ and $100 \%$.

\section{ACKNOWLEDGEMENTS}

This research is supported by the Ministry of Education, Culture, Research, and Technology of the Republic of Indonesia through the Basic Research Grant for Higher Education 2021 (No.

161/E4.1/AK.04.PT/2021).

\section{REFERENCES}

Arshad HMI, Naureen S, Saleem K, Ali S, Jabeen T, Babar MM. 2015. Morphological and biochemical characterization of Xanthomonas oryzae pv. oryzae isolates collected from Punjab during 2013. Advancements in Life Sciences. vol 2(3): 125-130.

Badan Pusat Statistik Provinsi Sumatera Utara. 2021. Provinsi Sumatera Utara dalam Angka 2021. Medan: BPS Provinsi Sumatera Utara, Indonesia. https://sumut.bps.go.id/.

Chen S, Wang C, Yang J, Chen B, Wang W, Su J, Feng A, Zeng L, Zhu X. 2020. Identification of the novel bacterial blight resistance gene Xa46 (t) by mapping and expression analysis of the rice mutant H120. Scientific Reports. vol 10(1): 1-11. doi: https://doi.org/10.1038/s41598-020-69639-y.

Chen X, Wei S, Yan Q, Huang F, Ma Z, Li R, Cen Z, Yan W, Li K. 2019. Virulence and DNA fingerprinting analysis of Xanthomonas oryzae pv. oryzae identify a new pathotype in Guangxi, South China. Journal of Basic Microbiology. vol 59(11): 1082-1091. doi: https://doi.org/10.1002/jobm.201900354.

Chukwu SC, Rafii MY, Ramlee SI, Ismail SI, Hasan MM, Oladosu YA, Magaji UG, Akos I, Olalekan KK. 2019. Bacterial leaf blight resistance in rice: a review of conventional breeding to molecular approach. Molecular Biology Reports. vol 46(1): 1519-1532. doi: https://doi.org/10.1007/s11033019-04584-2.

Deng WL, Lin HA, Shih YC, Kuo CC, Tzeng JY, Liu LYD, Huang ST, Huang CM, Chung CL. 2016. Genotypic and pathotypic diversity of Xanthomonas oryzae pv. oryzae strains in Taiwan. Journal of Phytopathology. vol 164(10): 745-759. doi: https://doi.org/10.1111/jph.12495.

Djatmiko HA, Prakoso B, Prihatiningsih N. 2011. Penentuan patotipe dan keragaman genetik Xanthomonas oryzae pv. oryzae pada tanaman padi di wilayah Karesidenan Banyumas. Jurnal Hama dan Penyakit Tumbuhan Tropika. vol 11(1): 35-46. doi: https://doi.org/10.23960/j.hptt.11135-46.

Fatimah F, Rangkuti SMS, Mustopa AZ, Suryani S. 2021. Molecular detection of Xanthomonas oryzae pv. oryzae from West Java and its in vivo pathogenicity test. AIP Conference Proceedings. vol 2353(1): 1-7. doi: https://doi.org/10.1063/5.0052632.

Gautam RK, Singh PK, Sakthivel K, Srikumar M, Kumar N, Kumar K, Singh AK, Roy SD. 2015. Analysis of pathogenic diversity of the rice bacterial blight pathogen (Xanthomonas oryzae pv. oryzae) in the Andaman Islands and identification of effective resistance genes. Journal of Phytopathology. vol 163(6): 423-432. doi: https://doi.org/10.1111/jph.12338.

He YW, Cao XQ, Poplawsky AR. 2020. Chemical structure, biological roles, biosynthesis and regulation of the yellow xanthomonadin pigments in the phytopathogenic genus Xanthomonas. Molecular Plant-Microbe Interactions. vol 33(5): 705-714. doi: https://doi.org/10.1094/MPMI-1119-0326-CR.

Islam MR, Alam MS, Khan AI, Hossain I, Adam LR, Daayf F. 2016. Analyses of genetic diversity of bacterial blight pathogen, Xanthomonas oryzae pv. oryzae using IS1112 in Bangladesh. Comptes Rendus Biologies. vol 339(9-10): 399-407. doi: https://doi.org/10.1016/j.crvi.2016.06.002.

Joshi JB, Arul L, Ramalingam J, Uthandi S. 2020. Advances in the Xoo-rice pathosystem interaction and its exploitation in disease management. Journal of Biosciences. vol 45(1): 1-17. doi: https://doi.org/10.1007/s12038-020-00085-8.

Kementerian Pertanian. 2015. Pengendalian penyakit kresek dan hawar daun bakteri. Subang: Balai Besar Penelitian Tanaman Padi, Balitbangtan, Kementerian Pertanian Republik Indonesia. https://bbpadi.litbang.pertanian.go.id/.

Kementerian Pertanian. 2021. Prakiraan serangan OPT utama padi, jagung, dan kedelai di Indonesia MT 2021. Karawang: Balai Besar Peramalan Organisme Penggangu Tumbuhan, Direktoral Jendral Tanaman Pangan, Kementerian Pertanian Republik Indonesia. http://sipetani.pertanian.go.id/.

Khan JA, Afroz S, Arshad HM, Sarwar N, Anwar HS, Saleem K, Babar MM, Jamil FF. 2014. Biochemical basis of resistance in rice against Bacterial leaf blight disease caused by Xanthomonas oryzae pv. oryzae. Advancement in Life Sciences. vol 1(3): 181-190.

Lang JM, Hamilton JP, Diaz MGQ, Van Sluys MA, Burgos MRG, Cruz CMV, Buell CR, Tisserat NA, Leach JE. 2010. Genomics Based Diagnostic Marker Development for Xanthomonas oryzae pv. oryzae and X. oryzae pv. oryzicola. Plant Disease. vol 94(3): 311-319. doi: https://doi.org/10.1094/PDIS-94-3-0311.

Luo D, Huguet-Tapia JC, Raborn RT, White FF, Brendel VP, Yang B. 2021. The Xa7 resistance gene guards the rice susceptibility gene SWEET14 against exploitation by the bacterial blight pathogen. Plant Communications. vol 2(3): 1-11. doi: https://doi.org/10.1016/j.xplc.2021.100164. 
Manigundan K, Kumar PP, Singh R, Sakthivel K, Gautam RK, Singh PK, Laha GS. 2017. Rep-PCR distinguishes rice bacterial blight pathogen (Xanthomonas oryzae pv. oryzae) strains of Indian mainland and bay islands. Journal of Plant Pathology. vol 99(3): 773-778. doi: https://dx.doi.org/10.4454/jpp.v99i3.3988.

Metsalu T, Vilo J. 2015. ClustVis: a web tool for visualizing clustering of multivariate data using Principal Component Analysis and heatmap. Nucleic Acids Research. vol 43(1): 566-570. doi: https://doi.org/10.1093/nar/gkv468.

Mishra D, Vishnupriya MR, Anil MG, Konda K, Raj Y, Sonti RV. 2013. Pathotype and genetic diversity amongst Indian isolates of Xanthomonas oryzae pv. oryzae. PloS One. vol 8(11): 1-11. doi: https://doi.org/10.1371/journal.pone.0081996.

Mondal KK, Meena BR, Junaid A, Verma G, Mani C, Majumder D, Khicher M, Kumar S, Banik S. 2014. Pathotyping and genetic screening of type III effectors in Indian strains of Xanthomonas oryzae pv. oryzae causing bacterial leaf blight of rice. Physiological and Molecular Plant Pathology. vol 86: 98-106.

https://doi.org/10.1016/j.pmpp.2014.03.005.

Noer Z, Hasanuddin H, Lisnawita L, Suryanto D. 2018. Pathotype profile of Xanthomonas oryzae pv. oryzae isolates from North Sumatra. IOP Conference Series: Earth and Environmental Science. vol 122(1): 1-8. doi: https://doi.org/10.1088/1755-1315/122/1/012142.

Oliva R, Ji C, Atienza-Grande G, Huguet-Tapia JC, Perez-Quintero A, Li T, Eom JS, Li C, Nguyen H, Liu B, Auguy F, Sciallano C, Luu VT, Dossa GS, Cunnac S, Schmidt SM, Slamet-Loedin IH, Cruz CV, Szurek B, Frommer WB, White FF, Yang B. 2019. Broad-spectrum resistance to bacterial blight in rice using genome editing. Nature Biotechnology. vol 37(11): 1344-1350. doi: https://doi.org/10.1038/s41587-019-0267-z.

Pachchigar KP, Khunt A, Hetal B. 2016. DNA quantification. In ICAR sponsored summer school on allele mining in crops: Methods and utilility. Gujarat: Department of Genetics \& Plant Breeding, College of Agriculture, Sardarkrushinagar Dantiwada Agricultural University. pp 4-7.

Patil B, Karegowda C, Narayanaswamy H, Wasimfiroz M. 2017. Biochemical variation among isolates of Xanthomonas oryzae pv. oryzae causing bacterial leaf blight in rice. International Journal of Chemical Studies. vol 5(6): 1265-1268.

Pradhan SK, Barik SR, Nayak DK, Pradhan A, Pandit E, Nayak P, Das SR, Pathak H. 2020. Genetics, molecular mechanisms and deployment of bacterial blight resistance genes in rice. Critical Reviews in Plant Sciences. vol 39(4): 360-385. doi: https://doi.org/10.1080/07352689.2020.1801559.

Quibod IL, Atieza-Grande G, Oreiro EG, Palmos D, Nguyen MH, Coronejo ST, Aung EE, Nugroho C, Roman-Reyna V, Burgos MR, Capistrano P,Dossa
SG, Onaga G, Saloma C, Cruz CV, Oliva R. 2020. The Green Revolution shaped the population structure of the rice pathogen Xanthomonas oryzae pv. oryzae. The ISME Journal. vol 14(2): 492-505. doi: https://doi.org/10.1038/s41396-019-0545-2.

Sakthivel K, Gautam RK, Manigundan K, Singh R, Ramalingam J, Laha GS, Kumar A, Velazhahan R. 2017. The host background of rice influences the resistance expression of a three genes pyramid (xa5+ xa13+ Xa21) to bacterial blight (Xanthomonas oryzae pv. oryzae) pathotypes of Indian mainland and Bay islands. Plant Breeding. vol 136(3): 357-364. doi: https://doi.org/10.1111/pbr.12472.

Sandhu AF, Khan JA, Ali S, Arshad HMI, Saleem K. 2018. Molecular characterization of Xanthomonas oryzae pv. oryzae isolates and its resistance sources in rice germplasm. Pakistan Science Mission Microbiology. vol 3(2): 55-61.

Saputra IK, Artika IM, Tasliah T. 2020. The blightresistance gene response to bacterial leaf blight disease in isogenic varieties through pathogenicity test. AIP Conference Proceedings. vol 2231(1): 17. doi: https://doi.org/10.1063/5.0002644.

Shahrestani AT, Kazempour MN, Ebadie AA, Elahinia SA. 2012. Genetic diversity of Xanthomonas oryzae pv. oryzae in rice fields of Guilan province (Iran) using RAPD markers. Agricultura Tropica et Subtropica. vol 45(2): 60-65. doi: https://doi.org/10.2478/v10295-012-0010-y.

Sudir S, Yuliani D. 2016. Composition and distribution of Xanthomonas oryzae pv. oryzae pathotypes, the pathogen of rice bacterial leaf blight in Indonesia. Agrivita, Journal of Agricultural Science. vol 38(2): 174-185.

doi: http://doi.org/10.17503/agrivita.v38i2.588

Suryadi Y, Samudra IM, Priyatno TP, Susilowati DN, Lestari P, Fatimah F, Kadir TS. 2016. Determination of pathotypes from Indonesian Xanthomonas oryzae pv. oryzae population causing bacterial leaf blight and their reactions on differential rice. Makara Journal of Science. vol 20(3): 109-118. doi: https://doi.org/10.7454/mss.v20i3.6241.

Suryadi Y, Kadir TS. 2017. Patogenisitas isolat bakteri Xanthomonas oryzae pv. oryzae dan pemantauan penyakit hawar daun bakteri pada padi galur isogenik. Berita Biologi. vol 16(2): 193-202. doi: http://dx.doi.org/10.14203/beritabiologi.v16i2.239 3.

Tasliah. 2012. Gen ketahanan tanaman padi terhadap bakteri hawar daun (Xanthomonas oryzae pv. oryzae). Jurnal Penelitian dan Pengembangan Pertanian. vol 31(3): 103-112. doi: http://dx.doi.org/10.21082/jp3.v31n3.2012.p\%25p.

Tasliah T, Mahrup M, Prasetiyono J. 2016. Identifikasi molekuler hawar daun bakteri (Xanthomonas oryzae pv. oryzae) dan uji patogenisitasnya pada galur-galur padi isogenik. Jurnal AgroBiogen. vol 9(2): $\quad 49-57$.

doi: 
http://dx.doi.org/10.21082/jbio.v9n2.2013.p49-57.

Timilsina S, Potnis N, Newberry EA, Liyanapathiranage $\mathrm{P}$, Iruegas-Bocardo F, White FF, Goss EM, Jones JB. 2020. Xanthomonas diversity, virulence and plant-pathogen interactions. Nature Reviews Microbiology. vol 18(8): 415-427. doi: https://doi.org/10.1038/s41579-020-0361-8.

Urrea-Valencia S, Melo ALDA, Gonçalves DRP, Galvão CW, Etto RM. 2021. Molecular Techniques to Study Microbial Wastewater Communities. Brazilian Archives of Biology and Technology. vol 64: 1-13. doi: https://doi.org/10.1590/1678-43242021200193.

Verma G, Mondal KK, Kulshreshtha A, Sharma M. 2019. XopR T3SS-effector of Xanthomonas oryzae pv. oryzae suppresses cell death-mediated plant defense response during bacterial blight development in rice. 3 Biotech. vol 9(7): 1-10. doi: https://doi.org/10.1007/s13205-019-1802-9.

Wahyudi AT, Meliah S, Nawangsih AA. 2011. Xanthomonas oryzae pv. oryzae bakteri penyebab hawar daun pada padi: isolasi, karakterisasi, dan telaah mutagenesis dengan transposon. Makara Journal of Science. vol 15(1): 89-96. doi: https://doi.org/10.7454/mss.v15i1.885.

Xu Z, Xu X, Gong Q, Li Z, Li Y, Wang S, Yang Y, Ma W, Liu L, Zhu B, Zou L, Chen G. 2019. Engineering broad-spectrum bacterial blight resistance by simultaneously disrupting variable TALE-binding elements of multiple susceptibility genes in rice. Molecular Plant. vol 12(11): 1434-1446. doi: https://doi.org/10.1016/j.molp.2019.08.006.

Yang SQ, Liu SY, Zhao S, Yu YH, Li RB, Duan CJ, Tang JL, Feng JX. 2013. Molecular and pathogenic characterization of new Xanthomonas oryzae pv. oryzae strains from the coastline region of Fangchenggang city in China. World Journal of Microbiology and Biotechnology. vol 29(4): 713720. doi: https://doi.org/10.1007/s11274-012-12277.

Yugander A, Sundaram RM, Ladhalakshmi D, Hajira SK, Prakasam V, Prasad MS, Madhav MS, Babu VR, Laha GS. 2017. Virulence profiling of Xanthomonas oryzae pv. oryzae isolates, causing bacterial blight of rice in India. European Journal of Plant Pathology. vol 149(1): 171-191. doi: https://doi.org/10.1007/s10658-017-1176-y.

Zhao Y, Qian G, Fan J, Yin F, Zhou Y, Liu C, Shen Q, $\mathrm{Hu}$ B, Liu F. 2012. Identification and characterization of a novel gene, hshB, in Xanthomonas oryzae pv. oryzicola co-regulated by quorum sensing and clp. Phytopathology. vol 102(3): 252-259. doi: https://doi.org/10.1094/PHYTO-06-11-0169. 